\title{
Notions of Atmosphere: Toward the Limits of Narrative Understanding
}

Snežana Milosavljević Milić

University of Niš, Faculty of philosophy, Cirila i Metodija 2, 18105 Niš, Serbia

https://orcid.org/0000-0002-0313-6849

snezana.milosavljevic.milic@filfak.ni.ac.rs

The change of methodological paradigms, introduced by postclassical narratology and especially its cognitivist orientation, has thus far not reflected on the phenomenon of atmosphere. This is somewhat surprising, if we consider that the contemporary conceptualization of atmosphere and the increased interest in the questions it brings forth arise from new phenomenology and phenomenological aesthetics, fields that have directly initiated the development of postclassical narratology. Starting with the phenomenological concept of atmosphere of $M$. Merleau-Ponty and H. Schmitz (atmosphere as an ecstasy of experience, a specific modus of presence with a quasi-objective and inter-subjective status fitting into the extra-linguistic framework, atmospheric perception as seizing the surfaceless space) and the aesthetic relevance of the concept (G. Böhme, T. Griffero, E. FischerLichte), this article presents the terminological instability and semantic vagueness of atmosphere and related terms within the narratological discourse of M. Bal, G. Prince, M.L. Ryan and P. Abbott (atmosphere as receptive and narrative disposition, the accompanying factor of morphological categories, the thematicpsychological distinctive characteristic of genre). The primary objective of the paper is to reexamine the methodological legitimacy of the concept of atmosphere, both regarding the limits of narrative understanding and its interpretative potential which might become relevant within cognitive theories of intertextuality (E. Panagiotidy, M. Juvan), while also being a humanistic response to the challenges of new epistemological paradigms and a return to the transcendental essence of literature.

Keywords: postclassical narratology / new phenomenology / focalization / atmosphere 
Poetic space, because it is expressed, assumes values of expansion.

It belongs to the phenomenology of those words that begin with "ex."

Gaston Bachelard

During the last decade, a certain phenomenon has earned a distinctive place in the phenomenological vocabulary, especially within new phenomenology. It occupies the attention of researchers so much that they are already using it to name a new turn in the humanities. This term is atmosphere, or more precisely, atmospheres, as the phenomenon is more often mentioned in plural form. In spite of the growing interest and an almost unquestionable fascination following the atmospheric turn - a fascination that also indicates the symptom of overcoming postmodern epistemological fear and entering a new, positive (transmodernistic) paradigm - it seems that the expected researcher resonance among modern narratologists is still lacking. This is even more surprising, as in this case the scientific focus fails to be accompanied by terminological innovations; on the contrary, the term atmosphere is widely naturalized both in various discourses and in everyday language. As most researchers have noted, we all have experience with atmosphere-we can name it, describe it, valorize it—, but none of us can precisely define what the term actually means.

The atmospheric turn is presently the most prominent exchange in new phenomenology and aesthetics. Starting with their insights, we will ask the rhetorical question of whether atmosphere is also a narrative phenomenon. The affirmative response represents a hypothesis, and its argumentation and support in the second part of the paper will take the form of a sketch of research perspectives provided by the application of the modern theoretical concept in the domain of literarycriticism research.

The term 'atmosphere' originally pertained to the geographic meaning of the aerial cover of Earth. The metaphorical meaning of the term appeared at the beginning of the nineteenth century and remains to this day, in the form of atmosphere as the qualitative characteristics of a situation or the mood caused by a situation. The usual use of conceptual metaphors in describing atmosphere-for example, in syntagmas such as heavy air, easy/soft wind, gloomy weather-indicates synesthesia as an important property of atmospheric perception.

Lexicographic entries of this term foreground at least two crucial aspects of atmosphere: its spatial character and its connection with 
feelings. These are actually not two separate or alternative properties. Their fusion represents the intriguing ontological status of atmosphere regarding the relationship between the subject and the object. As Stuart Grant claims, "the reference to atmosphere usually means that there is an unknown, something difficult to grasp, which needs to be clarified" (19).

The early signs of the atmospheric turn in the humanities are already contained in the change of epistemological paradigm achieved at the beginning of the twentieth century, with the abandonment of the Cartesian concept of subject. According to Damir Smiljanić, "the subject with no body and feelings is being replaced by a sensitive body," while "the substantiality of the objects of traditional gnoseology is simply dissolving in the wealth of synesthesia surrounding the body of the subject" (79).

The key initial role in the inauguration of the term 'atmosphere' as a new genius loci in the modern theory discourse ${ }^{1}$ belongs to Maurice Merleau-Ponty. He was the first to state the conceptual content of atmosphere and atmospheric perception in greater detail ${ }^{2}$ in his Phenomenology of Perception (1945). Using the syntagma "sensory experience" (86) as the "ecstasy of experience," Merleau-Ponty connected the "world of interacting sense" (262) and "the total life of the spectacle" (263). He emphasizes that pure experience is neither the awareness nor the pure being, but rather the communication of the subject with the non-transparent being. Merleau-Ponty assigns the attribute of "atmospheric" to the sensory sensations of color and sound, emphasizing the impossibility of their spatial localization, omnipresence and inherent coexistence with the bodily experience as an imminent aspect of the "synesthetic experience" (266). Here we have deliberately emphasized Merleau-Ponty's theses that are differentia specifica of the presently defined concept of atmosphere: its holistic nature, the spatial character of feelings as atmosphere, the ecstasy of experience, and the reach of sensory perception localized only "in between" the subject and the object, as an embodied experience.

The radicalization of these viewpoints is noticeable with the founder of new phenomenology, Herman Schmitz. His concept of feeling as atmosphere $^{3}$ has been widely reflected in modern humanities in the

${ }^{1}$ For the genesis of this term and its connection with the term 'Stimmung' in Heidegger's philosophy, see Popović (462) and Smiljanić (“Nova” 420).

${ }^{2}$ It may seem unusual that modern research by new phenomenologists and representatives of atmospheric aesthetics often overlooks the role of Merleau-Ponty, or only emphasizes the importance of $\mathrm{H}$. Schmitz as the forerunner of the atmospheric turn.

${ }^{3}$ Schmitz introduced the term 'atmosphere' in 1969. 
last few years. The nature of our "affective touch" matches the concept of surfaceless spaces. According to Schmitz, it also includes the space of sound, wind, silence, bodily reactions, and, water as a perceived dynamic volume (86-89). These are actually specific phenomena that are called "half-entities" by Schmitz, as they are not full things, but as quasi-objective facts, they carry the essential atmospheric potential. The synesthetic character of atmospheric perception, as "multi-presentable impression" (56) is at the same time immeasurable and infinite. Moreover, it is impossible to define it through the dichotomous categories of "external" and "internal" (Smiljanić, Sinestetika 192).

Promoting the thesis on the quasi-objective status of emotions, Schmitz simultaneously harshly criticized the "psychologistic-reductionist-introjectionist" concept of feelings as private spiritual states (91) and the modern constellationism in technical sciences, which he named "the neurological usurpers of philosophy" (52). Michael Hauskeller, as an author of one of the more recent reception of Schmitz's work, summarized the key episteme in the following way:

But what exactly are atmospheres? It seems obvious that they are not things. ... However, atmospheres are similar to things in that we don't find them in ourselves, like an emotion or a thought, but to all appearances in the world out there. Yet atmospheres are not sensory qualities either, like colours, sounds or smells, even though such qualities can certainly contribute to the nature of an atmosphere. Nor are they emotions. Atmospheres do not consist in purely cognitive associations, even though these can be a contributing factor. Atmospheres are felt, or experienced. Experience must here be understood as a mode of perception that necessarily involves emotions. I would define them as both tempered and tempering spaces. (42)

Directly inspired by Schmitz's concept of feelings as atmosphere and their quasi-objective status, as well as Walter Benjamin's concept of aura, Gernot Böhme defined the aesthetics of atmospheric synesthetic perception as an essential factor of various aesthetic practices.

Why is atmosphere "a fundamental concept of new aesthetics" (Böhme 13)? As a primary object of observing, but at the same time as that which "constitutes observation" (Lazić 323), appearing in the relation between the subject and the object, the pre-linguistic and prereflexive nature of atmosphere emphasizes the importance of live bodily experience in the context of aesthetic practices.

In correlation with Schmitz's concepts of semibeings, Böhme introduces (after Merleau-Ponty) a concept of "ecstasy of things" which refers to the way in which a thing steps out of itself and into the sur- 
rounding space, where it becomes palpably present (8). As Tina EngelsSchwarzpaul suggests, "The new aesthetics is above all a theory of sensory experience. ... Therefore the new aesthetics may be described ... as a theory of perception" (10).

The most consistent follower of Böhme's new aesthetics was the Italian theorist Tonino Griffero, who studied atmospheres as the aesthetics of emotional spaces. Griffero often touched upon the atmospheric experience of literature: for example, when talking about the simultaneous strength and fragility of the first impression or about the inevitability of being submerged as a synonym of atmospheric perception. Atmospheric perception is therefore a holistic and emotional being-in-the-world (Atmospheres 32). By evoking Merleau-Ponty's thesis on the authority of atmospheric perception, Griffero emphasizes an analysis of the authority of atmospheric feelings, considering them more stable and performative than a social norm or a thought. Griffero's contribution of modern research in this field may be observed in renaming atmospheric phenomenology with the more general "philosophy of situations" (Atmospheres 36), as the emphasis in studying atmosphere is now placed on the actual situation, seen as the multiple and chaotic state of things that can be distinguished from others precisely owing to its peculiar atmospheric tone (Atmospheres 36).

From this overview of the most important insights of new phenomenology and new aesthetics, it may be concluded that the phenomenon of space and the affective participation of persons with the space are key aspects of atmospheric perception. It is indicative that, in classical narratology, atmosphere was mostly referred to in the same situations where the issues of space are discussed. A return to its most prominent theorists does, however, symptomatically indicate a consensus in the generally accepted colloquial use of the term atmosphere, with a lack of any distinctive description of this term in a terminological, functional or semantic sense. This is, among other things, evidenced by the ellipsis in narratological dictionaries, ${ }^{4}$ as they do not mention the term atmosphere.

In her concise synthesis Narratology Introduction to the Theory of Narrative, Mieke Bal stressed the fact that the concept of space was one

${ }^{4}$ A rare example is the entry with this term in John Anthony Cuddon's The Penguin Dictionary of Literary Terms and Literary Theory. Cuddon defines atmosphere as "The mood and feeling, the intangible quality which appeals to extra-sensory perception, evoked by a work of art" (59). The author also cites "atmosphere of the mind," "the phrase invented by Henry James to denote what the subjective writer of the novel tries to convey to the reader. After a time we in a sense 'inhabit' the writer's mind, breathe that air and are permeated by his vision" (59). 
of the "most vague" concepts in narrative theories, in spite of its "selfevident" form (132). She emphasizes the difference between the terms 'space' and 'place,' which used to have the status of an axiom among narratologists. Bal considers the senses of sight, hearing and touch to be particularly important for the narrative presentation of space. Actually, $\mathrm{Bal}$ is less focused on the reader's (affective) response to the "atmosphere" of the narrative and more on "the relations between space and character" (138), where the aspect of focalization becomes crucial.

In his Dictionary of Narratology, Gerald Prince also found a place for atmosphere, but his term "setting" indicates the "spatiotemporal circumstances in which the events of a narrative occur" (italics by SMM), which might be "vague" or "precise" (88). It is also indicative that the atmospheric effect is indirectly prescribed to description as a form of storytelling. This morphological category therefore becomes the third distinctive property of atmosphere in traditional narrative theory (along with space and sensory mediation). In addition to other functions, Prince lists as a property of description the ability to set the "tone or mood of a passage" (19). Yet, just as in Bal, there is a lack of further explanation of this quality of description and space. We may therefore wonder whether such indifference or minimization was an approbation of the belief that atmosphere was not important enough in the story to be especially addressed. Or, more likely, that the explanative-methodological framework of discourse of classical narratology, as a factor of the linguistic turn, was still unable to position "in-between" to match the extralinguistic markers.

What changes were brought about by postclassical narratology? The interest in the affective nature of narrative and its semantic dimensions expressed through the concept of storyworld has directed the reader's receptive disposition toward the category of experience. In her book Towards the Natural Narratology, Monika Fludernik follows Paul Ricoeur and emphasizes the importance of narrative experience and its indubitable "peculiar dynamic" (18). By opposing the dominance of linguistics and the logic of syntax, Fludernik, after Claude Bremond and Jonathan Culler, notes the role of "experiential intentionality and dynamic teleology" (16) in the configuration of a holistic comprehension of narrative.

In Porter Abbott's concept of "literature of experience," as opposed to "literature of representation" (45), we may notice that the intention to position the atmospheric property between the recipient's experience and the logic (syntax) of the narrative, is the actual relation. From the perspective of Abbott's distinction of "two kinds of engagement 
with fiction - the experience of the text and its interpretation" (10), it may be inferred that Abbott's vision of an "experiential, processual, affective approach to interpretation with its focus on what happens to us over the course of an expressive or representational event (listening to a poem, reading a novel, watching a play)" (10) is close to the atmospheric experience in the reception of an artwork. In this sense, atmosphere might be the desired effect of the "silence of the text." According to Abbott, "What prose fiction contributed was silence, releasing words from what one might call their aural materiality" (59), but, at the same time it is the property providing specificity to the text.

The greatest advance toward discussing atmosphere in narratological theories is present in the cognitivist-oriented theories of immersion. The experience of reading as the perception of atmospheres has a holistic prefix that seems to unite the aspects of atmospheric perception previously separated in narratology, namely: space, description, the sensory experience of the character, and the affective resonance of the reader.

This psychological-phenomenological substitution of basic narratological terms made the appearance of the phenomenon of atmosphere practically impossible to disregard. It could have already been predicted from the emphasis on the holistic nature of storyworld. Moreover, the readiness to accept extralinguistic tools that could be used to describe this appearance had already quite openly hinted that the second wave of cognitive narratologists were much closer to the new-phenomenological paradigm than the linguistic paradigm. As Marie-Laure Ryan puts it, "In the metaphor of the text as world, the text is apprehended as a window on something that exists outside language and extends in time and space well beyond the window frame" (91). Of the five aspects of narrative space, the one combining the storyspace and the reader's imagination is particularly significant for atmospheric perception. Its hybrid character indicates the importance of intersubjective correlation, and the description of immersion through the metaphor of getting lost in the storyworld implicitly directs us to those characteristics of atmosphere that pertain to surfaceless space and the removal of its topographic coordinates. According to Ryan, atmospheric perception belongs to "the richer forms of perception" and "depends on the resonance in the reader's mind of the aesthetic features of the text: plot, narrative presentation, images, and style" (96). This specific feeling of space is atmospheric in its essence, and as such cannot be defined as a purely cognitive construct: Ryan claims that, "A sense of place is not the same thing as a mental model of space: through the former, readers 
inhale an atmosphere; through the latter, they orient themselves on the map of the fictional world" (123, italics by SMM).

Without additional explanation of the elements constitutive of atmospheric perception, Ryan emphasizes that one of the functions of atmosphere is to "facilitate the process of mental simulation and enrich our mental representation of all the episodes to come" (126). Such is the case with the introductory atmosphere, which opens the entryway into the storyworld, or, we would add, with the landscape, which has a background ambient function. Although it may be connected with the first impression, which, according to Griffero, is always atmospheric, the narrative experience of atmosphere "invites us to slow down the pace of reading" (Ryan 140). Perhaps this rhythm of affective resonance with regard to the imaginative storyworld should be the solution to the secret of aesthetic receptive competence.

The modern affective-narratological concept of atmosphere may be partially connected to another interpretation of the concept of experientiality. According to Marco Caracciolo, a representative of enactivist narratology, "experientiality [is] the 'impact' of engaging with a story, the extent to which it affects us" (15). This theoretical framework, which is close to the concept of Mimesis III (Ricoeur), supports hypotheses concerning the strong impression that atmospheric perception, as a product of the interaction between the recipient and the text, might have on the reader - its authoritative power.

The new-phenomenological approach to atmosphere described is, however, opposed to enactivism as a new paradigm for cognitive science, as it does not resolutely accept its scientism. On the other hand, both the immersion theory and enactivism maintain a resemblance to the concept of live body, which is the experience that matters to the recipient. The potential effects of the enactivistic and atmospheric approach to the narrative are indicated by the so-called "4E approach" which has become increasingly present as an orientation toward research of neglected aspects of cognition, including "cognition as embodied, embedded, enactive and extended" (Nikolić 545). ${ }^{5}$

By accepting the thesis on the "emotional or aesthetic quality inherent in the notion of atmosphere," Peter Stockwell, within the cognitive poetics, distinguishes between tone and atmosphere. As he explains, "atmosphere and atmospheric generally point to the world-evoked con-

5 "According to the controversial topic of broadened awareness, cognition does not take place only in the brain, and is not even limited by the body of the individual but extends to the outside world" (Clark in Nikolić 2017: 546, my translation). 
tent of the writing, and point to a direct and integrated relationship between the reader and that world," while "tone ... stands as a quality of the voice of the writing, and strongly indexes a mood, characteristic or trait of the writer's personality." "Tone can be described in text-linguistic terms ... Atmosphere requires a cognitive poetic description that takes account of the readerly sense of the contextual world of the depicted setting." However, Stockwell goes even further when he introduces the notion of "ambience," which is the "combination of tonal voice and atmospheric world," and which, due to its diffuse quality, is regarded as a "supertextual feature of discourse" ("Atmosphere" 360-374).

Since he believes that a "cognitive poetic account would begin by regarding atmosphere and tone as the global effects of ambience," Stockwell tries to use concrete examples from literary works to show the applicative effects of such theoretical starting points. Although it may be argued that the theoretical framework of the concepts offered is consistent and indubitably poetically relevant, the exact discourse in concrete analyses seems to oversimplify the problem. In this vein the final result does not achieve a degree of interpretation comparable to the strength of atmospheric perception.

When it comes to voice, it is worth noting another new contribution relating to audionarratology. Indeed, if "an enactive image has more of a holistic potential, tapping more deeply into the affective charges of the narrative in question" (Mildorf and Kinzel 7), one may reconsider the similarities between "multimodal sensations experienced in enactive imagery" with audionarrative and atmosphere as part of mental imagery that "has been redefined," according to Jarmila Mildorf and Till Kinzel, "in terms of enactment" (ibid).

The last contribution to be mentioned, but paradoxically possibly the first overall contribution to approaching this topic in literary studies, is Hans Ulrich Gumbrecht's book Atmosphere, Mood, Stimmung: On a Hidden Potential of Literature (2011). Although Gumbrecht asserts that "it is impossible to formulate a general theory about necessary conditions for producing Stimmung in general - or even in particular" (14), he believes "that researchers in the field of the 'human sciences' should rely more on the potential of counterintuitive thinking than on a pre-established 'path' or 'way'” (14). Essentially, Gumbrecht

${ }^{6}$ Similarly, Abbot regards voice as "the sensibility through which we hear the narrative, even when we are reading silently" (243). As Abbott puts it, "narrative voice colors the story it narrates" (72). 
is in line with aforementioned authors, as he is "interested in the atmospheres and moods that literary works absorb as a form of 'life' - an environment with physical substance, which 'touches us as if from inside" (16). In this way, Gumbrecht has tried to oppose "the skepticism of 'constructivism' and the 'linguistic turn' that concerns only ontologies of literature based on the paradigm of representation" (14).

\section{The applicative potential of the atmospheric turn in narratology}

The status assigned to the phenomenon of atmosphere in previous narratological theories, as a secondary companion of the chronotype (classical narratology) or as an important factor of the reader's participation in the storyworld (postclassical phase), suggests the potential methodological challenges posed by the introduction of this term. Some of these challenges can be illustrated through dichotomous antithetic pairs, where the first term matches the existing traditional concepts of narrative and the second term corresponds to their modifications assumed by the concept of atmosphere:

1) sequentiality of the narrative progression $v$ diffuse character of atmosphere;

2) degree of narrativity $v$ intensity of atmospheric (synesthetic) perception;

3) linguistic foundations $v$ s the (new) phenomenological method;

4) interpretation $v$ s hunch, intuition;

5) thematic or composition positioning vs position "in between";

6) narrative competence $v$ s emotional competence;

7) narrative as a cognitive style $v s$ atmosphere as a medium of perception.

On the one hand, these dichotomies reveal the issue of boundary aspects of narratological theories, while, on the other hand, they can encourage the applicative potential offered to these theories by the episteme of the atmospheric turn. Finally, in some newer approaches within postclassical narratology, it is already possible to recognize implicit agreements with new-phenomenological paradigms, as well as an openness toward interdisciplinary crossings. In what follows, I have tried to present some of the perspectives offered by such a cooperative platform, that is, the application of the concept of atmosphere to inter- 
preting narrative, especially regarding the topics of focalization, literary character, description as a narrative form, theory of intertextuality, and epitextual space.

Gerard Genette's famous concept of focalization was revised in postclassical narratology, both by introducing new types (such as hypothetical and conceptual focalization by David Herman, and plural focalization by Brian Richardson), and by the recognition a problem in zero focalization as an unsustainable and abstract type. The application of the concept of atmosphere enables the addition of the concepts of 'atmospheric focalization' and 'focalization of the first impression" to this taxonomy. In the former, atmosphere would have the role of a medium or filter of narrative information, ${ }^{8}$ providing a more sophisticated modus of what was previously included - mostly with insufficient precision-in the category of internal focalization or through character-perspective storytelling. In other words, the subject-object relation, or what happens between the subject and the object, is necessary for atmospheric focalization. This type of focalization acquired a more intensive role in the early twentieth century with modernism, where it appears in the role of painting with space (most commonly named "experienced space"). However, as with other types, atmospheric focalization is not just a perceptive aspect of "atmospheric space" (Griffero "Who's" 37). It can provide a tone to the psychological state of an individual or a group, which is an excellent way to evoke their expressive qualities (non-verbal and psychonarrative content), or state the main color of the objects within the storyworld. As such, atmospheric focalization is of special interest in the interpretation of narrative: it can be an interpretative point of orientation, flexible enough not to limit the

${ }^{7}$ As Mildorf and Kinzel put it, "Focalization, which is a controversial concept in narratology ..., is based on the visual metaphor of a lens through which one can take things, characters, actions in the storyworld into 'focus.' It seems that a mediasensitive narratology has to revise this concept to accommodate all the other sense perceptions, too" (14).

${ }^{8}$ In this sense, our concept of atmospheric focalization is different from Manfred Jahn's notion of ambient focalization. "Jahn describes ambient focalization as a case where spatial deictics are relaxed and the vision is mobile, hence beyond that of a single individual. One variety would be where the narrator's words convey the simultaneous takes of several individuals on the same object" (Margolin 55). "In ambient focalization, the field of subjectivity is shown as an ellipse: like a geometrical ellipse, which has two foci, ambient focalization is based on two (or more) F1's, depicting a thing summarily, from more than one side, possibly from all sides, considerably relaxing the condition of specific time-place anchoring, and allowing a mobile, summary, or communal point of view" (Jahn). 
interpretation to either the subjective intimate world of the character or the objective reference.

Although it is important for portraying the collective character, atmospheric focalization should not be considered equal to plural focalization, precisely because of its ambivalent, not purely anthropomorphic nature. It is therefore more appropriate to consider the desubjectivization of atmosphere, which is often found in combination with "intermental thought" (Palmer 218) and polylogue in presentations of group characters. This aspect of atmospheric focalization also supports efforts to interpret atmosphere as a social phenomenon, which is often mentioned in the most recent literature.

The introduction of atmospheric focalization also enables the differentiation of "focalization of first impression" as its subtype. As stated by Griffero, if atmosphere is a primary (aesthetic) perception, then the holistic nature of the first impression is in its essence synesthetic, as sensory perceptions are not differentiated yet. ${ }^{9}$ This type of focalization is present during the first introduction of space in the narrative, often in the introductory framework, in order to provide emphatic description. The "ecstasy of things as a specific modus of presence" (Böhme, "Atmosphere" 121) then combines the character and the space, and this constellation is manifested indicatively in the text by the crisis of language representation.

Bearing in mind Werner Wolfs concept "mise en cadre," one may conclude that atmosphere as a "mode of showing" "occurs when the text evokes, describes or narrates something in a framing part which, usually proleptically, but in some cases also analeptically, sheds light on the framed part and thus triggers a relevant cognitive frame in the recipient's mind that influences his or her interpretation" (Wolf 62). This aspect of focalizations of the first impression can be studied in more detail in the context of certain genres, as their distinctive initial cognitive marker of framework; for example, in an idyll or a horror story.

Considering the whole discussion of atmosphere presented, it is obvious that this concept may be a significant addition to theory of literary character. The emphasis on atmospheric perception and atmospheric focalization may make the hero more a passive than an active subject within the storyworld, a kind of resonance of synesthetic and pathic understanding. The concept of atmosphere, or feelings as atmo-

${ }^{9}$ The importance of the atmosphere of the first impression is particularly pronounced in theories of performing arts. It is an important factor enabling the specific "experience of spaceness" (Fischer-Lichte 140). 
sphere, might then cast a new light on the profile of the modernistic literary character, which has mainly been described in literature in an introjectionistic way. ${ }^{10}$ Instead of the overly sharp division between realism and modernism made in historical poetics, there would appear a sphere of soft, shaded transitions, more appropriate to the literary practice of the time. From this methodological position, it seems that the next stage of the pronounced symbolism of the hero could rely on a more detailed description of genesis. At the same time, this concept may be improved by the term "passant" (Rabinowitz 184), ${ }^{11}$ which was recently introduced into the theory of characters, and has indubitable methodological significance in the case of insufficiently theoretically described collective character. Friedlind Riedel claims that "atmosphere describes the ways in which a multiplicity of bodies is part of, and entrenched in, a situation that encompasses it" (85). This holistic and homogenizing role of atmosphere enables the metonymic description of the collective character, further aided by an atmospheric description of the social space as a distinctive factor in mass character.

The importance of perception and sensory mediation, as well as the synesthetic nature of atmosphere, suggests its interpretative potential in relation to description as a narrative form. As paradigmatic atmospheric phenomena (air, smoke, wind, wisp, sparkle, ray, sound, light), they are also almost an integral part of atmospheric description in literature. Naturally, the mere mention of these phenomena is not enough to assign the attribute of atmosphere to a description. An evident role must be assigned to the synesthetic play of senses, but it must also be noted that a more detailed description of the atmospheric non-object would lead to the loss of its atmospheric activity.

Is a description of atmosphere the same as an atmospheric description? While the first case would better suit pure description (mostly of space) and atmosphere as a motif, the second case would represent more of a hybrid form of description, that is "descriptive narration" (Mosher 427), ${ }^{12}$ and a more common use of atmospheric focalization.

\footnotetext{
${ }^{10}$ Smiljanić emphasized that the change in perspective in theory of understanding at the beginning of the twentieth century was manifested by "modification of the active state of subject into the passive state" (Sinestetika 82).

${ }^{11}$ According to Peter Rabinowitz, the "passant" is a character "on whom impressions are registered" (184).

${ }^{12}$ In one of the rare and excellent examples of applying the concept of atmosphere to literature, Timothy Chandler asks: "Is atmosphere itself representable?" (192), and emphasizes the paratactical (193) nature of "textual atmospheres" (192), which is otherwise also characteristic of descriptive narration.
} 
Within the context of historical poetics, it is possible to reconsider the hypothesis on description of atmosphere as a characteristic of the nineteenth-century realism, that is, atmospheric description as a sign of modernistic description. In this context, it is justified to discuss the role which an atmospheric description would have in the process of the modernistic aestheticization of the perception of reality, as a step away from the mimetic concept of reality and a turn toward its symbolization.

One of the most vital new tendencies regarding the application of the atmospheric episteme to literary criticism includes genealogy and the theory of intertextuality. The natural meeting of these two methodological pathways is enabled by the dominance of cognitivist theories, resulting in the relationship between texts and genres being increasingly discussed in categories of cognitive (meta)concepts. The invariant cutting through genre variations, free of stable morphologically-semantical boundaries, now finds its conceptual and interpretative background in atmosphere. Whether naming it by this term, or as allusion, more commonly as an echo, a resonance or an evocation, or as memory of text, modern theories of intertextuality use this re-actualization of phenomenological genealogy to search for a model of intertext flexible enough to be, so to speak, interpretatively sensitive and susceptible to the finest modulations and gradients. ${ }^{13}$

It seems that modern comparatists and literary theorists are increasingly open to this new — one could call it atmospheric — intertextuality. Enticed by Genette's theory of palimpsest, Zoran Konstantinović mentions citations not limited to a certain artistic procedure, not on the "surface structure of the text," but instead springing out of its depth. Such is the case with the "overlap and congruence of metaphysic quality" as that "feeling of unreachable originating in the wholeness of certain text" (Konstantinović 153, 163, 165, italics by SMM).

Maria-Eirini Panagiotidou introduced the concept of texture to explain the way of activating "semantic intertextual frames, which can be seen as the most idiosyncratic and loose way of bringing together two texts" (185). One of the criteria determining the properties of texture is resonance. As an "echo back a previous part of the text" ${ }^{\text {"14 }}$ or

${ }^{13}$ It must be noted, however, that the criterion of atmosphere has already been used as distinctively genre-related, although the lack of a methodological and terminological framework has prevented any systematic approach in that direction. One example is the definition of the gothic novel, the horror genre, the idyll, the dithyramb, or the fantasy genre.

${ }^{14}$ For more about the metaphor of echo, see Hollander. 
"alluding markers" (183), the "prolonged or momentary resonance" (176) may, obviously, be connected to atmospheric perception as an experience of reading, when there is no concrete linguistic synonymy between the texts in correlation. The concept of atmospheric experience is also close to the theory on "weak textuality, when readers are not able to point to particular textual occurrences as the text-specific activators of intertextual knowledge, but are still able to create an intertextual link based on what we may call the general texture of the text itself" (175). ${ }^{15}$ In this case, we conclude that two or more texts share the same or similar atmosphere, functioning as an implicit intertextual trigger.

In the domain of cognitive linguistics and cognitive poetics, Stockwell (Texture 458) directly connected the concept of texture as "the experienced quality of textuality" with the reader's experience of ambience as a "superordinate term encompassing atmosphere and tone." 16

By presenting a modern thesis against the linearity of text and meaning, Marko Juvan outlines the methodological consequences of the dominance of spatial metaphorics on the modern text theories. The concept of space becomes "key for the idea of intertextuality" (246), as, according to Juvan, intertextuality produces "transgressive spaces" (255). The intertextual evocations, or the mere impressions, of space, are indicative of the appearance of the "hybrid identity of floating spaces" (256). It is obvious that there is a certain compatibility between the concept of transgressiveness as an intertextual category and atmosphere, especially in the case of palimpsest transgression.

The further addition of a concept of atmosphere to cognitive theories of intertextuality may obviously concretize an insufficiently articu-

${ }^{15}$ In addition to texture, Panagiotidou introduces the dimension of "granularity"; "Readers may be able to recall very specific elements from previous texts, such as word occurrences or phrases, and connect them with the current text. ... However, another possibility is that they are able to locate some vague similarities which are only remotely related to the text or the word or phrase that prompted the activation of the intertextual knowledge, thus delineating the degree of granularity as low" (175). The same lexeme is also used by Griffero who describes atmosphere as "characterized by a qualitative microgranularity that is inaccessible to a naturalistic-epistemic perspective" (Quasi-Things x).

${ }^{16}$ On the other hand, Stockwell insists on the difference between ambience and resonance, as the former is "even less articulable and tangible" (Atmosphere 364). According to him, "Resonance is what a reader takes away from a striking reading - a definite thread of sensation that persists strongly after the text has been put aside. Ambience is much more mistily defined: it is the cognitive effect of cumulative but diffused associations across discourse" (Atmosphere 365). 
lated effect of reading, or support the work on adaptations and reconstruction of text ${ }^{17}$

Potential analogies between the various theoretical approaches to intertextuality indicate both the metaphoric meaning of the term atmosphere in the sense of a metadiscursive tool and its metonymic meaning including the possibility of intertextual relations. Terminological proliferation following the discourse of various intertextual theories, particularly regarding the nature of indirect relationships, implicitly reveals a potential dictionary of atmospheronyms, which would include the terms: allusion, echo, reflection, resonance, evocation, drive, impulse, hidden citation, memory of text.

The applicative potential of this "situational atmosphericness" (Griffero, Atmospheres 46) may be connected to the pragmatic aspects of literature in the epitextual space. It includes the atmosphere of buying the book, as "an atmosphere of assisted social relation between the producers and the consumers" (Bradić 522), its public presentation (book fair, gallery and other exhibition spaces) or reception (book promotions and meetings, the public and intimate space of reading), and the institution of literary awards. The hybrid character of these atmospheric spaces (as a milieu) assumes a dynamic co-relationship between the subject and the (adverbial) perception of the surroundings. Their activity is highly dependent on "atmospheric authority" and its conventions and "production" (Bradić 524) is constructed by cultural codes. From this standpoint, the library stands out for its atmospheric "voluminosity" (Griffero, Come rain 69), and many poetic as well as scientific books have been written on its magic. ${ }^{18}$ There is no doubt that further research on this aspect of literary pragmatics and epitextual narratives would also open the door for a meeting of geocriticism, narratology and theory of atmosphere.

\section{Conclusion}

In this article I have tried to present atmosphere as an indubitably narrative phenomenon and an important part of the story. The answer to the question of whether atmosphere is also a narratological

${ }^{17}$ One example may be the recent project of finishing the unfinished stories by Laza Lazarević, where the authors worked hard to transfer the atmosphere to the new narrative ending.

${ }^{18}$ On the library as a multiple spatial metaphor and its atmospheric activity, see Manguel 2006. 
phenomenon is not so clearcut, or is at least ambivalent. This article offers only sketches of potential methodological applications of this phenomenon. Recalling the opinion of Una Popović on the metadiscursive role of the term atmosphere as that which enables "the general phenomenological framework of any phenomenon" (454), atmosphere may be considered not as an object, but as a method of interpretation during the phenomenological reading of text. This hermeneutical challenge is present in literary works of modernism and the avant-garde, but also in contemporary trans-modernistic narrative practice. In the aforementioned theories of intertextuality, the concept of atmosphere is applicable both as proto-text (the "what") and method (the "how"), that is, in discussions of evocation. I therefore believe that the term atmosphere and related terms should be used to fill the void of ellipses in narratological dictionaries.

The persistent stubborn resistance to theorization of atmosphere in narratology should not, however, be neglected. It is evidence of the difficulties (both methodological and epistemological) pertaining to the limits of narrative understanding ${ }^{19}$ as experience of the simultaneous danger and attractiveness that we feel in the embrace of the lacuna and energeia of the literary text, something that is at the same time present and absent. This is the very "tension between the experience of reading a text and the analytical work of interpreting" (Abbott 10).

One may assume that this heavy breathing in the diluted air of the quasi thing of atmosphere is the extralinguistic extra that, by resisting language conceptualization (or exactly because of that), drives further thinking about this phenomenon. Indeed, one can agree with Gumbrecht that "the dimension of Stimmung discloses a new perspective on and possibility for the - 'ontology of literature" (7), as well as that "concentrating on atmospheres and moods offers literary studies a possibility for reclaiming vitality and aesthetic immediacy that have, for the most part, gone missing" (11). We should never give up hope, even if we are aware of the danger of the utopian dream of understanding the transcendental being of literature.

${ }^{19}$ As Richard Walsh puts it, "things may appear to make sense even while we are unable to make sense of them." By relating a mystical sense of wonder to the unnarratable, Walsh considers that it can help clarify our cognitive difficulties with emergence in complex systems (49-60). 


\section{WORKS CITED}

Abbott, Porter. Real Mysteries: Narrative and the Unknowable. Columbus: The Ohio State University Press, 2013.

Bachelard, Gaston. The Poetics of Space. Boston, Massachusetts: Beacon Press Books, 1994.

Bal, Mieke. Narratology: Introduction to the Theory of Narrative. Toronto, Buffalo, and London: University of Toronto Press, 1999.

Böhme, Gernot. "Atmosphere as the Fundamental Concept of a New Aesthetics." Thesis Eleven 36.1 (1993): 113-126.

Böhme, Gernot. Atmospheric Architectures: The Aesthetics of Felt Spaces. London, New York: Bloomsbury Academic. An imprint of Bloomsbury Publishing Plc, 2017.

Bradić, Stevan. “Atmosfere i estetski rad: 'nova estetika' Gernota Böhmea." Filozofska istraživanja 37.3 (2017): 513-528.

Caracciolo, Marco. "Narrative, Meaning, Interpretation: An Enactivist Approach." Phenomenology and the Cognitive Sciences 11.3 (2012): 367-384.

Chandler, Timothy. "Locus amoenus: Pastoral Atmosphere of Virgil's Eclogues." Colloquy: Text Theory Critique 23 (2012): 185-207.

Cuddon, John Anthony. The Penguin Dictionary of Literary Terms and Literary Theory. London: Penguin Books. 1992.

Engels-Schwarzpaul, Tina. "Approaching Atmospheres: Translator's Introduction." Böhme, Gernot. Atmospheric Architectures: The Aesthetics of Felt Spaces. London, New York: Bloomsbury Academic, An imprint of Bloomsbury Publishing Plc, 2017. 1-11.

Fisher-Lichte, Erika. Estetika performativne umjetnosti. Trans. Sulejman Bosto. Sarajevo; Zagreb: Šahirpašić, 2009.

Fludernik, Monika. Towards a 'Natural' Narratology. New York: Routledge, 2005.

Genette, Gerard. Paratexts: Thresholds of interpretation. Cambridge, New York, Melbourne: Cambridge University Press, 2001.

Grant, Stuart. "Performing an Aesthetics of Atmospheres." Aesthetics 23.1 (2013): $12-32$.

Griffero, Tonino. “Who's Afraid of Atmospheres (and of Their Authority)?” Lebenswelt 4.1 (2014): 193-213.

Griffero, Tonino. Quasi-Things, The Paradigm of Atmospheres. Albany (NY): State University of New York Press, 2017.

Griffero, Tonino. "Something more: Atmospheres and Pathic Aesthetics." Atmosphere/ Atmospheres: Testing a New Paradigm. Eds. Tonino Griffero and Giampiero Moretti. Milano-Udine: Mimesis International, 2018. 75-89.

Griffero, Tonino. "Come Rain or Come Shine ...: The (Neo)Phenomenological Willto-Presentness." Studi di estetica 46.IV.2 (2018): 57-73.

Gumbrecht, Hans Ulrich. Atmosphere, Mood, Stimmung: On a Hidden Potential of Literature. Stanford: Stanford University Press, 2012.

Hauskeller, Michael. "The Concept and the Perception of Atmospheres." Designing Atmospheres. Ed. Jürgen Weidinger. Berlin: Universitätsverlag 2018. 41-54.

Hollander, John. The Figure of Echo: A Mode of Allusion in Milton and After. Berkeley and Los Angeles: University of California Press, 2018.

Jahn, Manfred. "More Aspects of Focalisation: Refinements and Applications." Recent Trends in Narratological Research: Papers from the Narratology Round Table ESSE 4. Ed. John Pier. Tours: Presses universitaires François-Rabelais, 1999. 85-110. Web, 10. 07. 2019. 
Juvan, Marko. Nauka o književnosti u rekonstrukciji. Trans. Miljenko Vitezović. Beograd: Službeni glasnik, 2011.

Konstantinović, Zoran. Komparativno vidjenje srpske književnosti. Novi Sad: Svetovi, 1993.

Lazić, Davor. "Bemeova estetika atmosfera." Aktuelnost i budućnost estetike. Beograd: Estetičko društvo Srbije, 2015. 315-331.

Manguel, Alberto. The Library at Night. Toronto: Alfred. A. Knopf, 2006.

Margolin, Uri. "Focalization: Where Do We Go from Here?" Point of View, Perspective, and Focalization: Modeling Mediation in Narrative. Eds. Peter Hühn, Wolf Schmid, Jörg Schönert. Berlin: Walter de Gruyter, 2009. 41-57.

Merleau-Ponty, Maurice. Phenomenology of Perception. London and New York: Taylor and Francis e-Library, 2005.

Mildorf, Jarmila, and Till Kinzel. Audionarratology: Interfaces of Sound and Narrative. Berlin: De Gruyter, 2016.

Mosher, Harold F. Jr. "Toward a Poetics of 'Descriptized' Narration.” Poetics Today 12.3 (1991): 425-445.

Nikolić, Olga. "Utjelovljena svijest i naturalizirana fenomenologija." Filozofska istraživanja 37.3 (2017): 545-557.

Palmer, Alan. Fictional Minds. Lincoln and London: University of Nebraska Press, 2004.

Panagiotidou, Maria-Eirini. "A Cognitive Approach to Intertextuality: The Case of Semantic Intertextual Frames.” Newcastle Working Papers in Linguistics 17 (2011): $173-187$.

Popović, Una. "Pojam atmosfere u novoj fenomenologiji Hermanna Schmitza." Filozofska istraživanja. 37.3 (2017): 449-464.

Prince, Gerald. Dictionary of Narratology. Lincoln and London: University of Nebraska Press, 2003.

Rabinowitz, Peter J. "They Shoot Tigers, Don't They?: Path and Counterpoint in The Long Goodbye." A Companion to Narrative Theory. Eds. James Phelan and Peter J. Rabinowitz. Australia: Blackwell Publishing, 2005. 181-192.

Riedel, Friedlind. "Atmosphere." Affective Societies: Key Concepts. Eds. Jan Slaby and Christian von Scheve. New York: Routledge, 2019. 85-95.

Ryan, Marie-Laure. Narrative as Virtual Reality, Immersion and Interactivity in Literature and Electronic Media. Baltimore and London: The Johns Hopkins University Press, 2001.

Schmitz, Herman. Kratki uvod u novu fenomenologiju. Trans. Damir Smiljanić. Beograd: Akademska knjiga, 2018.

Smiljanić, Damir. Sinestetika: skica patičke teorije saznanja. Novi Sad: Adresa, 2011.

Smiljanić, Damir. "Nova fenomenologija." Filozofska istraživanja 37.3 (2017): 417-421.

Stockwell, Peter. "Atmosphere and Tone." The Handbook of Stylistics. Eds. Peter Stockwell and Sara Whiteley. Cambridge: Cambridge University Press, 2014. 360-374.

Stockwell, Peter. “Texture." The Bloomsbury Companion to Stylistics. Ed. Violeta Sotirova. Bloomsbury Academic, 2015. 458-475.

Walsh, Richard, "Sense and Wonder: Complexity and the Limits of Narrative Understanding." Narrating Complexity. Eds. Richard Walsh and Susan Stepney. Cham: Springer, 2018. 49-60.

Wolf, Werner. "Mise en Cadre - A Neglected Counterpart to Mise en Abyme: A Frame Theoretical and Intermedial Complement to Classical Narratology." Postclassical Narratology, Approaches and Analyses. Eds. Jan Alber and Monika Fludernik. Columbus: The Ohio State University Press, 2010. 58-82. 


\section{Pojmovanja atmosfere: $\mathrm{k}$ mejam pripovednega razumevanja}

Ključne besede: postklasična naratologija / nova fenomenologija / fokalizacija / atmosfera

Spremenjene metodološke paradigme, ki jih je prinesla postklasična naratologija in še posebej njena kognitivistična usmeritev, fenomenu atmosfere do zdaj niso posvečale veliko razmisleka. To nekoliko preseneča, če upoštevamo, da sodobna konceptualizacija atmosfere in povečano zanimanje za vprašanja, ki jih prinaša, izhajata iz nove fenomenologije in fenomenološke estetike, področij torej, ki sta neposredno prispevali $\mathrm{k}$ razvoju postklasične naratologije. $\mathrm{V}$ prispevku začenjam s fenomenološkim konceptom atmosfere po M. Merleau-Pontyju in H. Schmitzu (atmosfera kot ekstaza izkušnje, poseben način prisotnosti s kvaziobjektivnim in intersubjektivnim statusom, ki se prilega zunajjezikovnemu okviru, dojemanje atmosfere kot brezpovršinskosti prostora) in estetskim pomenom tega koncepta (G. Böhme, T. Griffero, E. Fischer-Lichte), nato pa predstavljam terminološko nestabilnost in semantično nejasnost atmosfere ter povezanih izrazov znotraj naratološkega diskurza M. Bal, G. Princea, M-L. Ryan and P. Abbotta (atmosfera kot receptivna in pripovedna naravnanost, spremljevalni dejavnik morfoloških kategorij, tematsko-psihološka značilnost žanra). Najpomembnejši cilj prispevka je, da ponovno preuči metodološko legitimnost koncepta atmosfere, tako kar zadeva meje pripovednega razumevanja kot njenega interpretativnega potenciala, ki bi lahko postal relevanten v okviru kognitivnih teorij intertekstualnosti (E. Panagiotidy, M. Juvan), po drugi strani pa gre tudi za humanistični odgovor na izzive novih epistemoloških paradigem in povratek $\mathrm{k}$ transcendentalnemu bistvu literature.

1.01 Izvirni znanstveni članek / Original scientific article

UDK 82.0-3

DOI: https://doi.org/10.3986/pkn.v43.i1.02 